\title{
Effect of case management on neonatal mortality due to sepsis and pneumonia
}

\author{
Anita K M Zaidi ${ }^{*}$, Hammad A Ganatra', Sana Syed ${ }^{1}$, Simon Cousens², Anne CC Lee ${ }^{3}$, Robert Black ${ }^{3}$, \\ Zulfiqar A Bhutta', Joy E Lawn ${ }^{4}$
}

\begin{abstract}
Background: Each year almost one million newborns die from infections, mostly in low-income countries. Timely case management would save many lives but the relative mortality effect of varying strategies is unknown. We have estimated the effect of providing oral, or injectable antibiotics at home or in first-level facilities, and of in-patient hospital care on neonatal mortality from pneumonia and sepsis for use in the Lives Saved Tool (LiST).
\end{abstract}

Methods: We conducted systematic searches of multiple databases to identify relevant studies with mortality data. Standardized abstraction tables were used and study quality assessed by adapted GRADE criteria. Meta-analyses were undertaken where appropriate. For interventions with biological plausibility but low quality evidence, a Delphi process was undertaken to estimate effectiveness.

Results: Searches of 2876 titles identified 7 studies. Among these, 4 evaluated oral antibiotics for neonatal pneumonia in non-randomised, concurrently controlled designs. Meta-analysis suggested reductions in allcause neonatal mortality (RR $0.7595 \% \mathrm{Cl}$ 0.64- 0.89; 4 studies) and neonatal pneumonia-specific mortality (RR 0.58 95\% Cl 0.41- 0.82; 3 studies). Two studies (1 RCT, 1 observational study), evaluated community-based neonatal care packages including injectable antibiotics and reported mortality reductions of $44 \%$ ( $R R=0.56$, $95 \% \mathrm{Cl} 0.41-0.77)$ and $34 \%(\mathrm{RR}=0.66,95 \% \mathrm{Cl} 0.47-0.93)$, but the interpretation of these results is complicated by co-interventions. A third, clinic-based, study reported a case-fatality ratio of $3.3 \%$ among neonates treated with injectable antibiotics as outpatients. No studies were identified evaluating injectable antibiotics alone for neonatal pneumonia. Delphi consensus (median from 20 respondents) effects on sepsis-specific mortality were $30 \%$ reduction for oral antibiotics, $65 \%$ for injectable antibiotics and $75 \%$ for injectable antibiotics on pneumonia-specific mortality. No trials were identified assessing effect of hospital management for neonatal infections and Delphi consensus suggested $80 \%$, and $90 \%$ reductions for sepsis and pneumonia-specific mortality respectively.

Conclusion: Oral antibiotics administered in the community are effective for neonatal pneumonia mortality reduction based on a meta-analysis, but expert opinion suggests much higher impact from injectable antibiotics in the community or primary care level and even higher for facility-based care. Despite feasibility and low cost, these interventions are not widely available in many low income countries.

Funding: This work was supported by the Bill \& Melinda Gates Foundation through a grant to the US Fund for UNICEF, and to Saving Newborn Lives Save the Children, through Save the Children US.

\footnotetext{
* Correspondence: anita.zaidi@aku.edu

'Department of Paediatrics and Child Health, the Aga Khan University,

Karachi, Pakistan

Full list of author information is available at the end of the article
} 


\section{Background}

Deaths occurring in the neonatal period each year account for $41 \%$ (3.6 million) of all deaths in children under 5 years [1]. The majority of these deaths occur in low income countries and almost 1 million of these deaths are attributable to infectious causes including neonatal sepsis, meningitis and pneumonia [1]. These deaths occur because of lack of preventive care (clean birth care, breastfeeding) and appropriate case management [2]. Delays in treating neonatal infections of even a few hours may be fatal. Delays in illness recognition and care seeking, a dearth of primary health care providers, and limited access to facility care contribute to these deaths [3]. Recent trials have demonstrated the effect of community-based packages for prevention and treatment of neonatal bacterial infections, with the potential to save many lives $[4,5]$.

Therapy with appropriate antibiotics and supportive management in neonatal nurseries is the cornerstone of management of neonatal sepsis and pneumonia, with strong biological plausibility that such therapy saves lives. Yet the quality of evidence is understandably affected by the ethical impossibility of undertaking randomized trials of antibiotic management compared with no antibiotic management. Nevertheless, given the limited access to care for sick neonates in low income countries, it is important to assess the potential mortality effect of oral antibiotics and injectable antibiotics delivered in domiciliary or primary care settings. Case management for hospitalized neonates is more expensive, but to guide policy and program investments we also need to know how much more effective it is compared to care delivered at home or in primary care settings.

The objective of this review is to provide estimates of the effectiveness of three interventions in preventing neonatal deaths from severe infection: (i) case management with oral antibiotic therapy alone for pneumonia and sepsis; (ii) case management with injectable antibiotics ( \pm oral antibiotics) as an outpatient or at home for neonatal sepsis /meningitis and pneumonia; and (iii) hospital-based case management, including injectable antibiotics, intravenous fluids, oxygen therapy, second line injectable antibiotics if needed, and other supportive therapy (Table 1). These mortality effect estimates are used in the Lives Saved Tool (LiST) software, a userfriendly tool that estimates the number of lives saved by scaling up key interventions and helps in child survival planning in low income countries $[6,7]$.

\section{Methods}

\section{Searches}

We searched all published literature as per CHERG systematic review guidelines[7]. Databases searched were PubMed, Cochrane Libraries and WHO regional
Table 1 Definitions of interventions reviewed

Oral antibiotic therapy alone

- Administration of oral antibiotics in the community for neonatal sepsis, meningitis, or pneumonia

Injection therapy alone

- Administration of intramuscular antibiotics, at home or in firstlevel facilities, for neonatal sepsis, meningitis, or pneumonia

Hospital-based management as an inpatient with supportive care - Administration of intravenous antibiotics

- Wider choice of antibiotics including broad spectrum antibiotics

$\circ$ Option of using frequent/higher dosage if needed to maintain

high blood antibiotic levels or coverage for meningitis,

$\circ$ Access to second-line antibiotic therapy for neonates with

treatment failure on first line antibiotics

- Intravenous access and administration of intravenous fluids if needed

- Oxygen supplementation if required

- Access to appropriate diagnostic procedures, such as monitoring

of pulse, blood pressure, and oximetry reading, as well as

monitoring/correction of hypoglycemia if required

databases from 1990 until April 2009 and included publications in any language (Figure 1). Search terms included various combinations of: sepsis, meningitis and pneumonia. For sepsis and pneumonia management at a hospital level we conducted two parallel searches (Figures 2 and 3). These were broader as we also wanted to identify studies reporting incidence and case fatality ratios (CFR) for a related study on global burden of neonatal sepsis. Titles and abstracts were reviewed and studies were included if data on one of the following outcomes was provided: all-cause mortality, sepsis/meningitis/pneumonia mortality and/or CFR. Furthermore, extensive efforts were made to contact investigators and program managers for unpublished data.

\section{Inclusion/exclusion criteria, abstraction}

We reviewed all available observational studies, randomized controlled trials, systematic reviews, and metaanalyses, which included neonates and principally involved the management of serious neonatal infections. The search was limited to "humans". We examined studies published from 1990 until April 2009.

We included randomized controlled trials, studies with concurrent controls, and observational studies with no control group if mortality outcomes were reported. All studies meeting final inclusion criteria were double data abstracted into a standardized form. We abstracted key variables with regard to the study identifiers and context, study design and limitations, intervention specifics, and mortality outcomes. We assessed the quality of each of these studies using a standard table employing an adapted version of GRADE[8] developed by the Child Health Epidemiology Reference Group (CHERG) [7]. For studies which reported mortality outcomes that were not neonatal specific, we contacted the authors to 


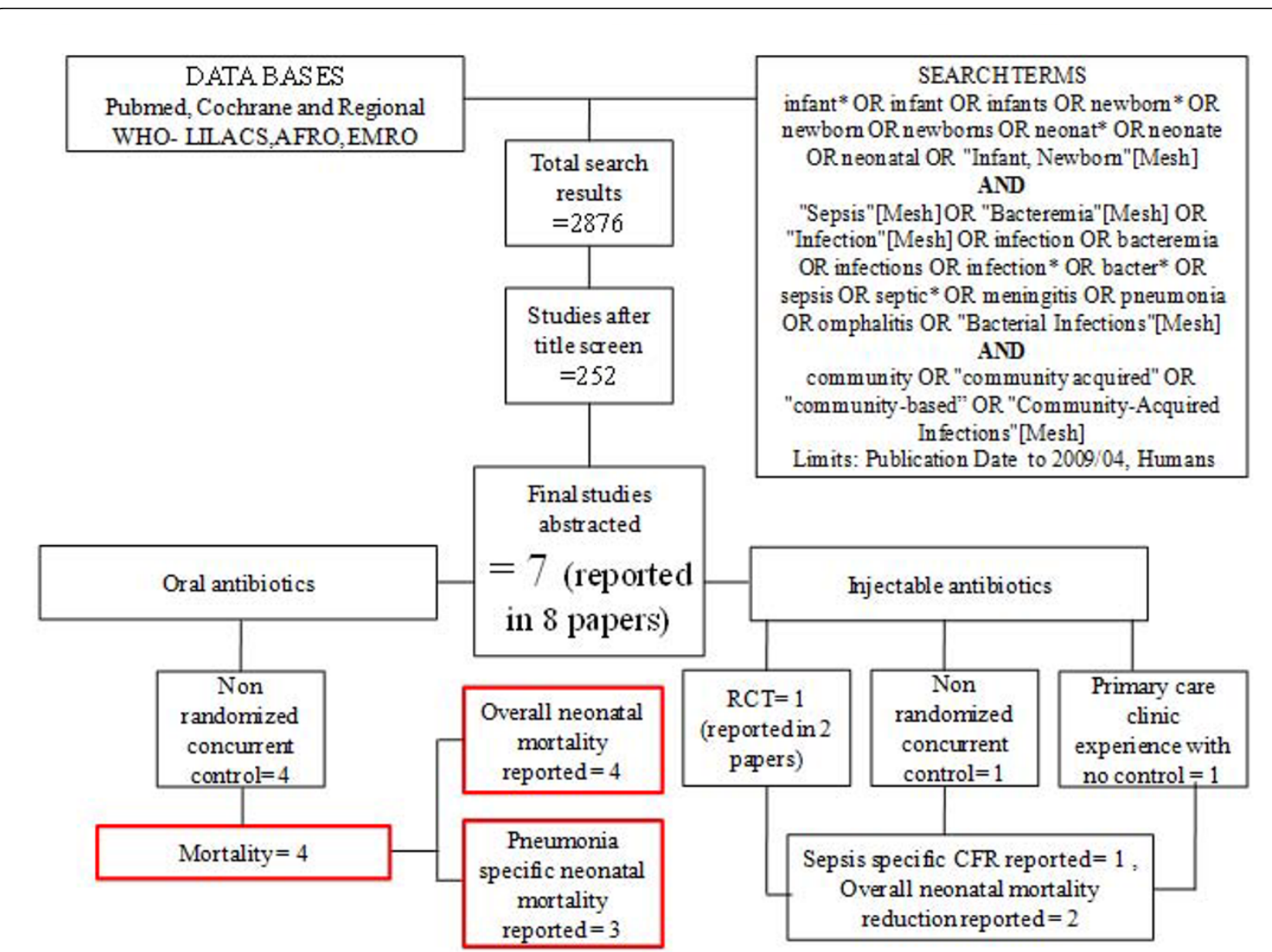

\section{[Red signifies new meta-analysis]}

Figure 1 Searches and screening for community based management of sepsis and pneumonia.

request the neonatal-specific data. All studies that were coded are included in Additional File 1.

\section{Case definition of sepsis}

During our review of selected studies we were unable to find a standard definition for clinical neonatal sepsis or pneumonia (Table 2). Each study used different criteria although most are a variation on WHO IMCI approach. We therefore decided to accept authors' definitions of sepsis and pneumonia, recognizing that these non-specific definitions lower mortality outcome estimates as many "non-sepsis" cases are included in an effort to maximize sensitivity.

\section{Analyses and summary measures}

All studies reporting mortality data for pneumonia and sepsis management, in community and hospital settings, were summarized according to the overall quality of evidence for each outcome and each data input type using an adapted version of the GRADE 21 protocol table [7]. When appropriate, we conducted meta-analyses to obtain pooled estimates of the risk ratios, using either the Mantel-Haenzsel or, when there was evidence of heterogeneity, the DerSimonian-Laird random effects estimator. 95\% confidence intervals (CI) were also calculated. Statistical analyses were performed using STATA 10.0 (http://www.stata.com).

\section{Delphi Process for Establishing Expert Consensus}

For intervention-outcome combinations for which we did not identify moderate quality evidence, we sought expert consensus via the Delphi method. Individuals invited to participate were experts in newborn health and sepsis representing six WHO regions (South Asia, 


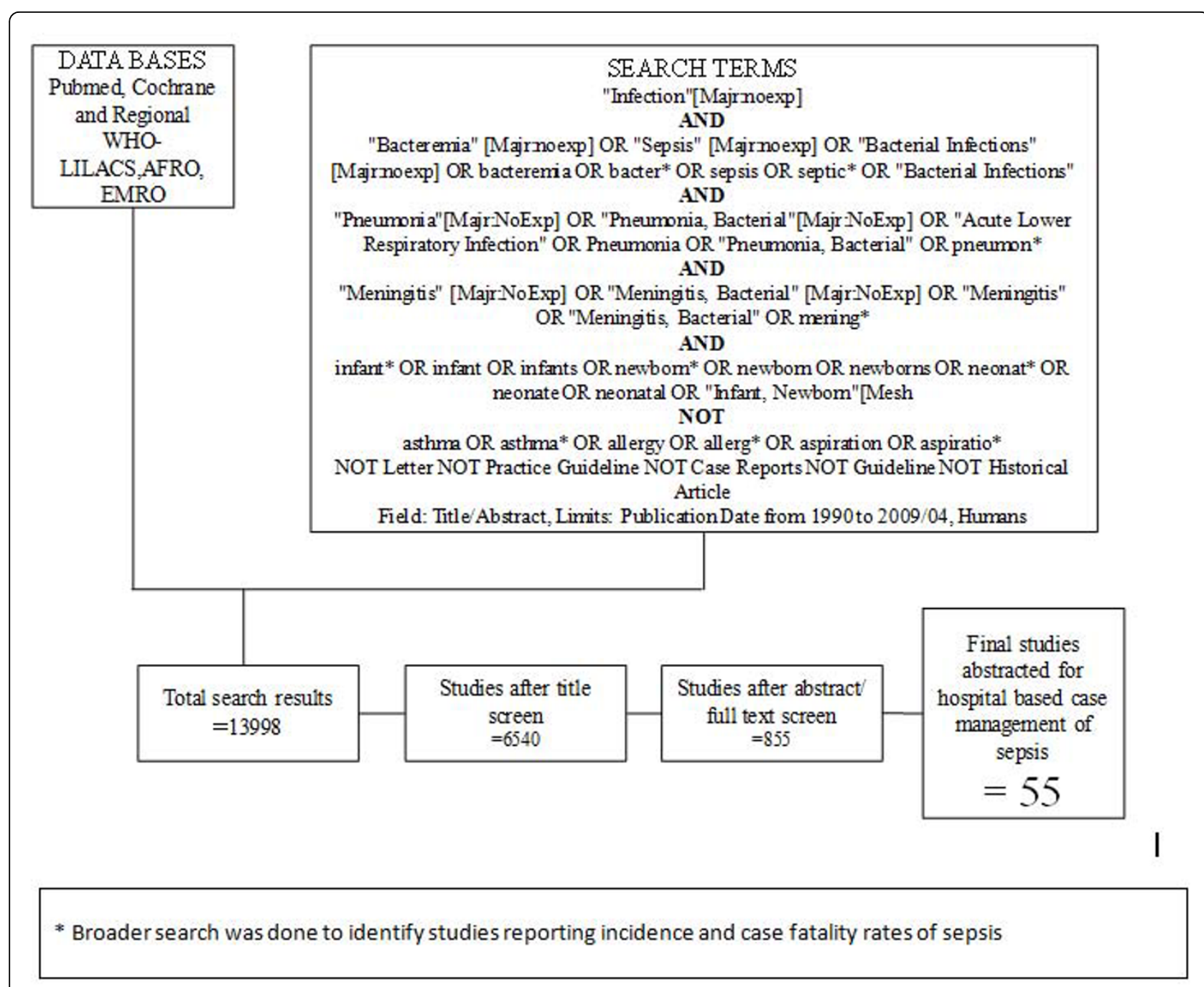

Figure 2 Searches and screening for hospital management of sepsis.

Africa, Western Europe, Eastern Europe, North America, Australia), and including multiple disciplines international health, pediatric infectious diseases, clinical neonatology, and general pediatrics. Twenty (of twenty-three experts invited) agreed to participate in the Delphi process. The questionnaire was developed by JL, AZ, SC and SS, and refined after several rounds of pilot testing. The questionnaire was sent by email and included the background and aims of the Delphi and estimates of effect that were available from the literature for different scenarios. The median response and range were determined for each question. Consensus was defined a priori as an interquartile range in responses of not more than $30 \%$ for each question. For those estimates not reaching consensus, the plan was for results to be electronically distributed to the panel, virtual discussion allowed, and a second round of email questionnaires sent. However, consensus was achieved after one round of questionnaires and subsequent rounds were not necessary.

\section{Results}

\section{Studies identified}

Our systematic searches for community management of sepsis and pneumonia identified 2876 titles (Figure 1) and after screening of titles, abstracts and relevant full texts, we located 7 studies of interest (reported in 8 papers) [9-16]. We identified 4 non randomised concurrently controlled studies, which evaluated oral antibiotics for pneumonia (Table 5) [10,14-16]. Three of these studies did not report disaggregated neonatal outcomes in the primary papers, but neonatal outcomes were available through abstracted forms from an earlier metaanalysis by Sazawal et al [17]. For management of neonatal sepsis using injectable antibiotics, we located 3 studies (reported in 4 papers) [9,11-13]. There was one 


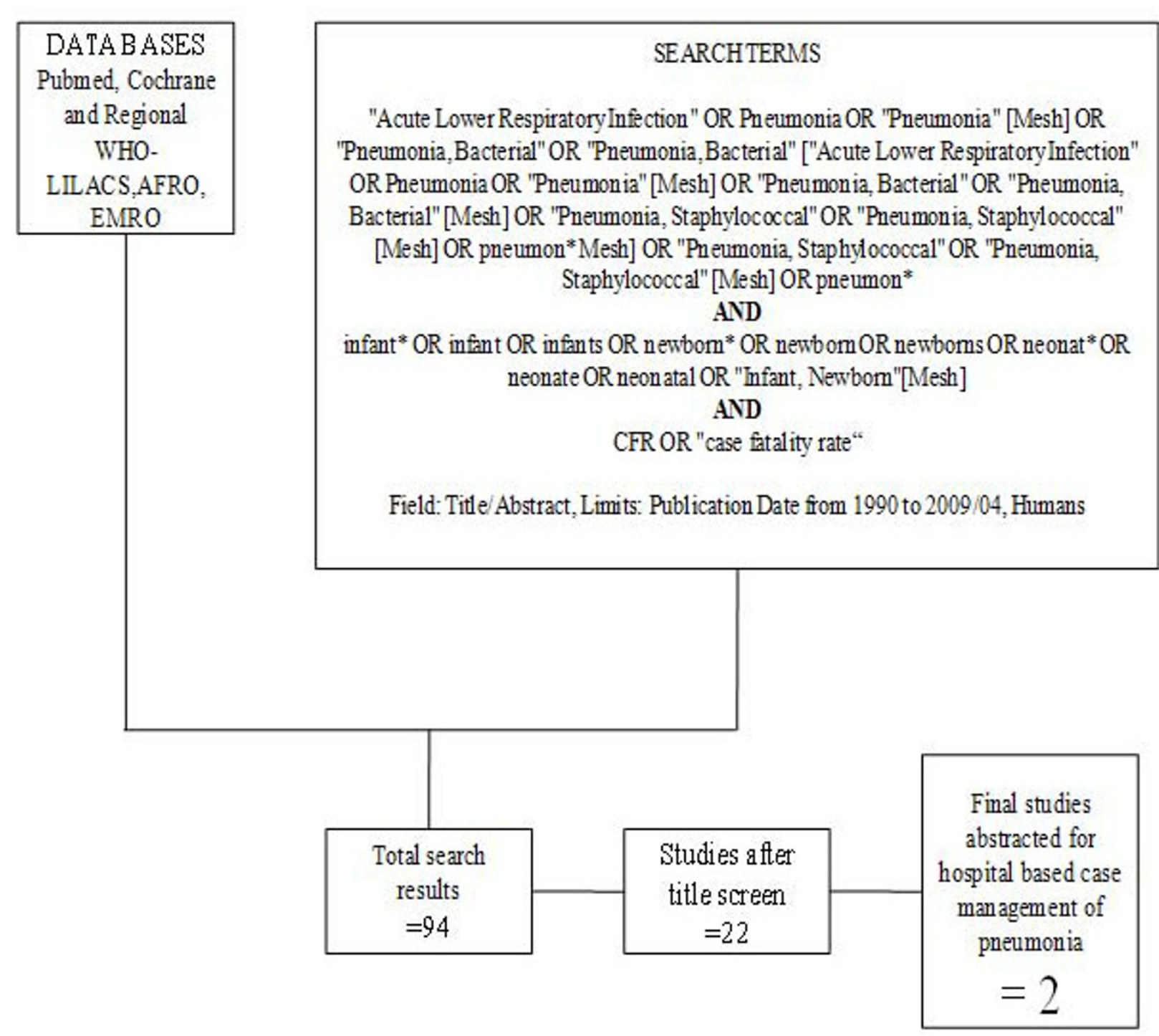

Figure 3 Searches and screening for hospital management of pneumonia.

observational primary clinic-based study without a control group [13], one RCT [12] and one non-randomised, concurrently controlled study [9]. The fourth paper reported observational data from individual infants evaluated during the RCT mentioned above and was not a separate study [11]. All the studies were from high neonatal mortality regions.

In our search for hospital-based studies of sepsis we found 55 studies from a total pool of 13998 studies which reported sepsis and/or meningitis mortality outcomes (Figure 2) [18-70]. For pneumonia, we found two studies from a total pool of 94 studies (Figure 3) [71,72].

The details of each study and quality assessment using GRADE are summarised in Tables 3, 4, 5, and 6.
Evidence for effectiveness of oral antibiotic therapy alone

Unpublished neonatal data were obtained from the principal investigators of the four studies identified and a new meta-analysis was done to update that of Sazawal et al[17]. We performed meta analyses for two outcomes: oral antibiotics were associated with reductions in both all-cause mortality (4 studies [10,14-16]: RR 0.75 95\% CI 0.64- 0.89) (Figure 4) and pneumonia-specific mortality (3 studies $[10,15,16]$ : RR $0.5895 \%$ CI 0.41 0.82) (Figure 5). Limitations included non-randomization, estimation of intervention coverage as precise coverage estimates were not available;and variability between studies of the intensity of co-interventions. We found no studies of the effect of oral antibiotics on sepsis-specific mortality. The Delphi consensus (median) 
Table 2 Varying definitions of neonatal sepsis used by investigators and clinicians

\begin{tabular}{ll}
\hline Common signs of neonatal sepsis: \\
- Lethargy or irritability & - Respiratory distress \\
- Poor feeding & - Apnoea \\
- Vomiting & - Fever or hypothermia \\
- Jaundice & \\
\hline
\end{tabular}

Definition of neonatal sepsis used by Bang et al (1999) [9] Presence of two or more of the following signs:

- Weak or absent cry - Diarrhoea or persistent vomiting or

- Weak or reduced suckling abdominal distension

- Drowsy or unconscious - Grunting or severe chest indrawing

baby

- Respiratory rate of 60 or more

- Temperature more than

- Pus in skin or umbilicus

$37.2^{\circ} \mathrm{C}$ or less than $35^{\circ} \mathrm{C}$

Definition of neonatal sepsis used by Baqui et al (2008) [12]

Presence of one or more of the following signs:

- Convulsions $\quad$ Body Temperature $\leq 35.3^{\circ} \mathrm{C}$

- Unconsciousness - Many or severe skin pustules or blisters

- Fever $\geq 38.3^{\circ} \mathrm{C} \quad$ on single large area, or pus or redness

- Breathing $\geq 60$ per minute with swelling Severe chest indrawing

Definition of sepsis by Young Infant Clinical Signs Study Group (2008) [84]

Presence of one or more of the following signs:

- Difficulty feeding

- Convulsions

- Severe chest indrawing

- Movement only when

- Temperature $\geq 37.5^{\circ} \mathrm{C}$

stimulated

- Respiratory rate of 60 or

more was for a $28 \%$ reduction in sepsis-specific mortality with an interquartile range of $20 \%$ to $36.25 \%$ (Figure 6).

\section{Evidence for effectiveness of injectable antibiotic therapy} ( \pm oral antibiotics)

Three studies reported in four papers, were identified (Table 6) [9,11-13]. One, an RCT[12] evaluated the impact of a perinatal care package which included the administration of injectable antibiotics in domiciliary settings in situations where referral to hospital was not possible. This trial reported a reduction in all-cause neonatal mortality of $34 \%(\mathrm{RR}=0.66,95 \% \mathrm{CI} 0.47-0.93)$. A second paper from the same study reported that the CFR for neonates who were evaluated and actually treated with injectable antibiotics was $4.4 \%$ [11]. A nonrandomized, concurrently controlled study [9] also evaluated the impact of a home-based neonatal care package in which septic neonates were treated with injectable antibiotics when referral to hospital was not possible. The overall mortality reduction in the intervention arm of the trial was calculated to be $44 \%$ ( $R R=0.56$ 95\% CI 0.41-0.77). A third, uncontrolled study [13] based in a primary care clinic reported a CFR of 3.3\% among septic children treated with injectable antibiotics.

In both of the community-based studies $[9,12]$ injectable antibiotics were only one component of comprehensive

Table 3 GRADE assessment of studies of effect of case management on cause specific neonatal mortality due to pneumonia

\begin{tabular}{|c|c|c|c|c|c|c|c|c|}
\hline \multirow[b]{3}{*}{$\begin{array}{l}\text { No. of } \\
\text { studies }\end{array}$} & \multirow[b]{3}{*}{ Design } & \multirow[b]{3}{*}{ Limitations } & \multicolumn{3}{|l|}{ Quality Assessment } & \multicolumn{3}{|c|}{ Summary of Findings } \\
\hline & & & \multirow[b]{2}{*}{ Consistency } & \multirow[b]{2}{*}{$\begin{array}{l}\text { Generalizability } \\
\text { to Population } \\
\text { of Interest: } \\
\text { means to the } \\
\text { "population" }\end{array}$} & \multirow[b]{2}{*}{$\begin{array}{l}\text { Generalizability } \\
\text { of the } \\
\text { Intervention of } \\
\text { interest }\end{array}$} & \multicolumn{2}{|c|}{ No. of Events } & \multirow{2}{*}{\begin{tabular}{l}
\multicolumn{1}{c}{ Effect } \\
$\begin{array}{l}\text { Relative Risk } \\
(95 \% \mathrm{Cl})\end{array}$
\end{tabular}} \\
\hline & & & & & & Intervention & Control & \\
\hline \multicolumn{9}{|c|}{ Mortality Pneumonia - community based oral antibiotic studies } \\
\hline & $\begin{array}{l}1 \text { randomized } \\
3 \text { Non } \\
\text { randomized - } \\
\text { concurrent } \\
\text { control }\end{array}$ & $\begin{array}{l}\text { Studies are not } \\
\text { randomized, } \\
\text { coverage of } \\
\text { intervention are } \\
\text { estimates, exact data } \\
\text { not available, } \\
\text { intensity of co- } \\
\text { interventions varies } \\
\text { between studies }\end{array}$ & $\begin{array}{l}\text { Findings from the } 4 \\
\text { studies all show } \\
\text { direct mortality } \\
\text { reduction benefit, } \\
\text { although in } 3 \text { of the } \\
4 \text { studies included in } \\
\text { the meta analysis, } \\
\text { the effect reduction } \\
\text { is not significant. }\end{array}$ & $\begin{array}{l}\text { Yes, studies were } \\
\text { all done in high } \\
\text { neonatal } \\
\text { mortality regions. }\end{array}$ & $\begin{array}{l}3 \text { of the } 4 \\
\text { studies show } \\
\text { direct effect on } \\
\text { pneumonia } \\
\text { specific mortality. } \\
1 \text { shows effect } \\
\text { on overall } \\
\text { neonatal } \\
\text { mortality }\end{array}$ & $248 / 6542$ & $\begin{array}{l}63 / \\
4538\end{array}$ & $\begin{array}{l}{ }^{*} \text { All-cause } \\
\text { mortality } 0.75 \\
(0.64-0.89) \\
{ }^{*} \text { Pneumonia } \\
\text { Specific } 0.58 \\
(0.41-0.82)\end{array}$ \\
\hline \multicolumn{9}{|c|}{ Mortality Pneumonia - community based injectable antibiotic studies } \\
\hline \multicolumn{9}{|c|}{ No studies identified } \\
\hline \multicolumn{9}{|c|}{ Mortality Pneumonia - hospital-based case management } \\
\hline 2 & $\begin{array}{l}\text { Both } \\
\text { observational } \\
\text { study design }\end{array}$ & Not trials & $\begin{array}{l}\text { CFR: } 14.4 \%(28 / 195) \\
\text { and } 30.8 \%(8 / 26)\end{array}$ & $\begin{array}{l}\text { Both studies } \\
\text { from low income } \\
\text { South Asian } \\
\text { countries. }\end{array}$ & $\begin{array}{l}\text { The study } \\
\text { reporting higher } \\
\text { CFR had high } \\
\text { proportion ( } 60 \%) \\
\text { of LBW babies. }\end{array}$ & N/A & N/A & N/A \\
\hline
\end{tabular}


Table 4 GRADE assessment of studies of case management on cause specific neonatal mortality due to neonatal sepsis

\begin{tabular}{|c|c|c|c|c|c|c|c|c|}
\hline \multirow[b]{3}{*}{$\begin{array}{l}\text { No. of } \\
\text { studies }\end{array}$} & \multirow[b]{3}{*}{ Design } & \multicolumn{3}{|c|}{ Quality Assessment } & \multirow[b]{3}{*}{$\begin{array}{l}\text { Generalizability of the } \\
\text { Intervention of interest }\end{array}$} & \multicolumn{3}{|c|}{ Summary of Findings } \\
\hline & & \multirow[b]{2}{*}{ Limitations } & \multirow[b]{2}{*}{ Consistency } & \multirow[b]{2}{*}{$\begin{array}{l}\text { Generalizability } \\
\text { to Population } \\
\text { of Interest }\end{array}$} & & \multicolumn{2}{|c|}{ No. of Events } & \multirow{2}{*}{\begin{tabular}{l}
\multicolumn{1}{c|}{ Effect } \\
Relative \\
Risk \\
$(95 \% \mathrm{Cl})$ \\
\end{tabular}} \\
\hline & & & & & & Intervention & Control & \\
\hline \multicolumn{9}{|c|}{ Mortality Sepsis - community based oral antibiotic studies } \\
\hline \multicolumn{9}{|c|}{ No studies identified } \\
\hline \multicolumn{9}{|c|}{ Mortality Sepsis - community based injectable antibiotic studies } \\
\hline 2 & Observational & $\begin{array}{l}1 \text { study has no control } \\
\text { group }\end{array}$ & $\begin{array}{l}\text { Yes: both } \\
\text { show low } \\
\text { CFRs }(3.3 \% \text {, } \\
4.4 \%)\end{array}$ & $\begin{array}{l}\text { Yes, both studies } \\
\text { were done in } \\
\text { high neonatal } \\
\text { mortality regions. }\end{array}$ & Direct & $133 / 2211$ & N/A & N/A \\
\hline 1 & $\begin{array}{l}\text { Non } \\
\text { randomized - } \\
\text { concurrent } \\
\text { control trial }\end{array}$ & $\begin{array}{l}\text { Change in sepsis specific } \\
\text { mortality rate in } \\
\text { intervention and control } \\
\text { areas is not given }\end{array}$ & $\begin{array}{l}\text { The results } \\
\text { of this study } \\
\text { were } \\
\text { consistent } \\
\text { with the } \\
\text { RCT }\end{array}$ & $\begin{array}{l}\text { Yes, study was } \\
\text { done in a high } \\
\text { neonatal } \\
\text { mortality region. }\end{array}$ & Indirect & $54 / 1783$ & $\begin{array}{l}113 / \\
2048\end{array}$ & $\begin{array}{l}0.56 \\
(0.41- \\
0.77)\end{array}$ \\
\hline 1 & $\mathrm{RCT}$ & $\begin{array}{l}\text { Sepsis specific reduction } \\
\text { in mortality not given }\end{array}$ & $\begin{array}{l}\text { Reported } \\
\text { similar } \\
\text { results as } \\
\text { study above }\end{array}$ & $\begin{array}{l}\text { Yes, study was } \\
\text { done in a high } \\
\text { neonatal } \\
\text { mortality region. }\end{array}$ & Indirect & $82 / 2812$ & $\begin{array}{l}125 / \\
2872\end{array}$ & $\begin{array}{l}0.22 \\
(0.07- \\
0.71) \\
\text { CFR }=4.4 \% \\
\end{array}$ \\
\hline \multicolumn{9}{|c|}{ Mortality Sepsis/Meningitis - case management in hospitals } \\
\hline 55 & $\begin{array}{l}\text { All } \\
\text { observational } \\
\text { study designs }\end{array}$ & $\begin{array}{l}\text { All observational with } \\
\text { varied study setting, from } \\
\text { high-income to low- } \\
\text { income countries. In low- } \\
\text { income countries self- } \\
\text { selecting populations } \\
\text { because most births } \\
\text { happen at community } \\
\text { level. }\end{array}$ & $\begin{array}{l}\text { CFR range } \\
\text { from } 67 \text { to } \\
6.7 \%\end{array}$ & $\begin{array}{l}\text { *NMR LEVEL5=5 } \\
\text { studies } \\
\text { NMR LEVEL4=17 } \\
\text { studies } \\
\text { NMR LEVEL 3= } 5 \\
\text { studies } \\
\text { NMR LEVEL2=5 } \\
\text { studies } \\
\text { NMR LEVEL1=22 } \\
\text { studies } \\
\text { Multi country=1 }\end{array}$ & $\begin{array}{l}\text { In countries with high } \\
\text { skilled attendance } \\
\text { hospital data } \\
\text { generalizable to all } \\
\text { population. But in low- } \\
\text { income countries, hospital } \\
\text { data not given as most } \\
\text { births at home }\end{array}$ & N/A & N/A & N/A \\
\hline
\end{tabular}

*NMR LEVELs ( $1=$ NMR <5 per 1000 live births, 2=NMR 6 to 15 per 100 live births, $3=$ NMR 15 to 30 per 100 live births, 4=NMR $31-45$ per 100 live births $5=$ NMR $>45$ per 100 live births.

community-based newborn care packages, and therefore the effectiveness of injectable antibiotics alone in the community cannot be reliably estimated. The Delphi consensus for the effect of injectable antibiotics was for a $65 \%$ reduction (interquartile range of 50-70\%) in sepsis-specific mortality and $75 \%$ reduction (interquartile range of 70$81.25 \%$ ) in pneumonia-specific mortality in communitybased settings (Figure 6).

\section{Evidence for effectiveness of inpatient hospital case management}

We found no trials assessing the impact of hospitalbased case management and the observational studies of hospital management showed wide variation in effect. Searches conducted for studies reporting CFRs in neonates with pneumonia in health facilities revealed very few data. Two studies were identified with authordefined neonatal pneumonia; both were from low income, non-industrialised settings and reported CFRs of $14.4 \%$ [72] and $30.8 \%$ [71].
CFRs for neonatal sepsis, adjusted for the proportion of very low birth weight babies in the study, were plotted against national percentage skilled delivery, as a proxy for access to hospital-based case management of neonatal sepsis. In countries with a high proportion of births attended by skilled attendants, the predicted CFR for sepsis was $9.5 \%$, whereas in countries with a low proportion $(<30 \%)$ skilled birth attendance, the predicted CFR for sepsis with hospital care is $20-30 \%$ (Figure 7). A $68 \%$ reduction in the CFR for neonatal sepsis is predicted as one moves from $0 \%$ to $100 \%$ skilled birth attendance. This reduction is likely to under estimate the effect of hospital-based case management since skilled birth attendance is likely to be a poor surrogate for effective facility case management of neonatal infections, but was used in the absence of coverage data for case management

Although the quality of evidence is low according to GRADE criteria, the recommendation for case management of neonatal infections is strong, and this is standard practice globally. Table 7 provides a summary of 
Table 5 Summary of community-based studies for case management with oral antibiotics for and effect on cause specific neonatal mortality due to pneumonia

\begin{tabular}{|c|c|c|c|c|c|c|c|c|c|c|}
\hline \multirow[t]{2}{*}{$\begin{array}{l}\text { Ref and } \\
\text { year }\end{array}$} & \multirow[t]{2}{*}{ Country } & \multirow[t]{2}{*}{ Setting } & \multirow[t]{2}{*}{$\begin{array}{l}\text { Study } \\
\text { design }\end{array}$} & \multirow[t]{2}{*}{ Therapy given } & \multirow{2}{*}{$\begin{array}{l}\text { Other } \\
\text { interventions } \\
\text { in package }\end{array}$} & \multirow{2}{*}{$\begin{array}{l}\text { Coverage of } \\
\text { antibiotic } \\
\text { case } \\
\text { management } \\
\text { (\% of those } \\
\text { who need it) }\end{array}$} & \multirow[t]{2}{*}{$\begin{array}{l}\text { Intervention } \\
\text { group (N/D) }\end{array}$} & \multirow{2}{*}{$\begin{array}{l}\text { Control } \\
\text { group } \\
\text { (N/D) }\end{array}$} & \multicolumn{2}{|c|}{$\begin{array}{c}\text { Effect size RR } \\
\quad(95 \% \mathrm{Cl})\end{array}$} \\
\hline & & & & & & & & & $\begin{array}{l}\text { RR of } \\
\text { Sepsis } \\
\text { specific } \\
\text { NMR }\end{array}$ & $\begin{array}{l}\text { RR of } \\
\text { Pneumonia } \\
\text { specific } \\
\text { NMR }\end{array}$ \\
\hline $\begin{array}{c}\text { Pandey } \\
1991 \\
{[16]}\end{array}$ & Nepal & Rural & $\begin{array}{c}\text { Non } \\
\text { randomized } \\
\text {-concurrent } \\
\text { control }\end{array}$ & $\begin{array}{l}\text { Cotrimoxazole } \\
4 \mathrm{mg} / \mathrm{kg} \mathrm{BD} \text { for } \\
5 \text { days. } \\
\text { Chloramphenicol } \\
\text { if no } \\
\text { improvement }\end{array}$ & $\begin{array}{l}\text { Maternal } \\
\text { education, and } \\
15 \% \text { measles } \\
\text { immunization } \\
\text { coverage of } \\
\text { children }\end{array}$ & $\begin{array}{c}<40-70 \% \\
\text { (estimates as } \\
\text { per study PIs) }\end{array}$ & $81 / 681$ & $16 / 681$ & $\begin{array}{c}0.85 \\
(0.65- \\
1.12)\end{array}$ & $\begin{array}{c}0.89 \\
(0.46-1.72)\end{array}$ \\
\hline $\begin{array}{c}\text { Mtango } \\
\mathbf{1 9 8 6} \\
{[15]}\end{array}$ & Tanzania & Rural & $\begin{array}{l}\text { Non } \\
\text { randomized } \\
\text {-concurrent } \\
\text { control }\end{array}$ & $\begin{array}{c}\text { Cotrimoxazole } \\
\text { PO }\end{array}$ & $\begin{array}{l}\text { Health } \\
\text { education to } \\
\text { mothers about } \\
\text { symptoms \& } \\
\text { signs of ARI } \\
\text { and referring } \\
\text { severe cases to } \\
\text { the next higher } \\
\text { level of care. }\end{array}$ & $\begin{array}{c}<40-70 \% \\
\text { (estimates as } \\
\text { per study PIs) }\end{array}$ & $37 / 1638$ & $7 / 1638$ & $\begin{array}{c}0.70 \\
(0.47- \\
1.07)\end{array}$ & $\begin{array}{c}0.44 \\
(0.18-1.07)\end{array}$ \\
\hline $\begin{array}{c}\text { Khan } \\
1990 \\
{[14]}\end{array}$ & Pakistan & Rural & $\begin{array}{c}\text { Non } \\
\text { randomized } \\
\text {-concurrent } \\
\text { control }\end{array}$ & CotrimoxazolePO & $\begin{array}{l}\text { Qualified nurses } \\
\text { monitored and } \\
\text { supervised } \\
\text { CHW activities } \\
\text { and with } \\
\text { assistance of } \\
\text { the CHWs, } \\
\text { conducted } \\
\text { frequent, } \\
\text { informal, } \\
\text { interactive } \\
\text { health } \\
\text { education } \\
\text { programs }\end{array}$ & $\begin{array}{c}<40-70 \% \\
\text { (estimates as } \\
\text { per study Pls) }\end{array}$ & $26 / 2690$ & $9 / 686$ & $\begin{array}{c}0.74 \\
(0.35- \\
1.57)\end{array}$ & $\begin{array}{l}\text { Did not } \\
\text { report } \\
\text { pneumonia } \\
\text { specific } \\
\text { mortality }\end{array}$ \\
\hline $\begin{array}{c}\text { Bang } \\
1990 \\
{[10]}\end{array}$ & India & Rural & $\begin{array}{c}\text { Non } \\
\text { randomized } \\
\text {-concurrent } \\
\text { control }\end{array}$ & $\begin{array}{c}\text { Cotrimoxazole } 2.5 \\
\mathrm{ml} \text { twice daily for } \\
7 \text { days }\end{array}$ & $\begin{array}{l}\text { Mass health } \\
\text { education } \\
\text { about } \\
\text { childhood } \\
\text { pneumonia }\end{array}$ & $\begin{array}{c}76 \% \text { (for } \\
\text { children <5) }\end{array}$ & $104 / 1533$ & $31 / 1533$ & $\begin{array}{c}0.70 \\
(0.54- \\
0.91)\end{array}$ & $\begin{array}{c}0.52 \\
(0.33-0.82)\end{array}$ \\
\hline
\end{tabular}

the effect of case management on neonatal sepsis and pneumonia cause specific mortality, and GRADE of the estimate. Therefore the Delphi process was used to provide estimates for the effect of hospital care. The Delphi consensus was for a $80 \%$ reduction in sepsis-specific mortality (interquartile range $75 \%$ to $85 \%$ ), and a $90 \%$ reduction in pneumonia-specific mortality (interquartile range $88.75 \%$ to $95 \%$ ) (Figure 6).

\section{Discussion}

Infections including sepsis, meningitis and pneumonia are responsible for almost a million neonatal deaths annually. Neonates are more susceptible to severe infections and the progression of disease is more rapid due to developmental immunodeficiency, resulting in high
CFRs. Also, a significant proportion of infections may arise early, after vertical transmission from the mother [73]. Therefore, timely identification and appropriate management with antibiotics is an important strategy to reduce the burden of neonatal mortality due to infections. We have previously reported the evidence from observational and experimental studies in low income countries for community-based management of neonatal infections (pneumonia and sepsis) with oral and injectable antibiotics [74-76]. We have now undertaken a systematic review of available evidence, including from industrialized countries and facility settings, and where the quality of evidence is low we have undertaken a Delphi expert process to estimate the cause-specific mortality effect. 
Table 6 Summary of community-based studies including injectable antibiotics for case management of neonatal sepsis (observational, quasi experimental, and RCT)

\begin{tabular}{|c|c|c|c|c|c|c|c|c|c|}
\hline $\begin{array}{l}\text { Ref and } \\
\text { year }\end{array}$ & Country & Setting & Study design & $\begin{array}{l}\text { Therapy } \\
\text { given }\end{array}$ & $\begin{array}{c}\text { Other interventions in } \\
\text { package }\end{array}$ & $\begin{array}{l}\text { Coverage } \\
\text { of } \\
\text { antibiotic } \\
\text { case } \mathrm{mx} \\
\text { (\% of } \\
\text { those } \\
\text { who need } \\
\text { it) }\end{array}$ & $\begin{array}{l}\text { Intervention } \\
\text { group (N/D) }\end{array}$ & $\begin{array}{l}\text { Control } \\
\text { group } \\
\text { (N/D) }\end{array}$ & $\begin{array}{c}\text { Effect } \\
\text { size RR } \\
(95 \% \mathrm{Cl})\end{array}$ \\
\hline $\begin{array}{c}\text { Bang } \\
1999[9]\end{array}$ & India & Rural & $\begin{array}{c}\text { Non- } \\
\text { randomized } \\
\text { concurrent } \\
\text { control study }\end{array}$ & $\begin{array}{l}\text { Gentamicin } \\
\text { IM and } \\
\text { cotrimoxazole }\end{array}$ & $\begin{array}{l}\text { Comprehensive perinatal } \\
\text { care package including } \\
\text { trained TBAs, VHWs } \\
\text { undertaking }>6 \text { home } \\
\text { visits, targeting of small } \\
\text { babies for extra support, } \\
\text { comm. mobilization for } \\
\text { healthy home behaviors } \\
\text { etc. }\end{array}$ & $\begin{array}{c}\text { Years } \\
1996-97 \\
85 \% 685 / \\
804 \\
\text { Years } \\
1997-98 \\
93 \% 913 / \\
979\end{array}$ & $54 / 1783^{*}$ & $\begin{array}{l}113 / \\
2048^{*}\end{array}$ & $\begin{array}{c}0.56 \\
(0.41-0.77)\end{array}$ \\
\hline $\begin{array}{l}\text { Bhandari } \\
1996[13]\end{array}$ & India & $\begin{array}{c}\text { Periurban/ } \\
\text { urban }\end{array}$ & Observational & $\begin{array}{l}\text { Cephalexin } \\
\text { PO and } \\
\text { amikacin IM }\end{array}$ & None & N/A & $\begin{array}{c}\text { 124/2007 Age } \\
\text { group }=1-2 \\
\text { mths }\end{array}$ & None & $\begin{array}{c}\text { No effect } \\
\text { size can } \\
\text { be } \\
\text { calculated } \\
\text { CFR }=3.3 \%\end{array}$ \\
\hline $\begin{array}{c}\text { Baqui } \\
2008[12]\end{array}$ & Bangladesh & Rural & $\begin{array}{c}\text { Cluster } \\
\text { randomized } \\
\text { trial }\end{array}$ & $\begin{array}{c}\text { Procaine } \\
\text { penicillin and } \\
\text { gentamicin }\end{array}$ & $\begin{array}{c}\text { Birth and newborn-care } \\
\text { preparedness postnatal } \\
\text { home visits for newborns } \\
\text { assessment on 1,3,7 days } \\
\text { of birth. Referral when } \\
\text { needed }\end{array}$ & $\begin{array}{l}41 \% \\
\text { estimated } \\
\text { from } \\
\text { adequacy } \\
\text { surveys }\end{array}$ & $82 / 2812$ & $\begin{array}{l}125 / \\
2872\end{array}$ & $\begin{array}{c}0.66 \\
(0.47-0.93)\end{array}$ \\
\hline $\begin{array}{c}\text { Baqui } \\
2009[11]\end{array}$ & Bangladesh & Rural & Observational** & $\begin{array}{c}\text { Procaine } \\
\text { penicillin and } \\
\text { gentamicin }\end{array}$ & $\begin{array}{l}\text { Referral for very severe } \\
\text { disease or possible very } \\
\text { severe disease with } \\
\text { multiple signs, by CHWs } \\
\text { to government subdistrict } \\
\text { hospitals. If the family was } \\
\text { unable to comply with } \\
\text { referral, the CHWs treated } \\
\text { local skin and umbilical } \\
\text { cord infections with } \\
\text { gentian violet and made } \\
\text { follow up visits to reassess } \\
\text { the infant. }\end{array}$ & N/A & $9 / 204$ & $24 / 112$ & $\begin{array}{c}0.22 \\
(0.07-0.71) \\
\text { CFR }=4.4 \%\end{array}$ \\
\hline
\end{tabular}

* Combined data from years 2 and 3 of trial i.e. 1996-1997 and 1997-1998.

**Observational data on individual infants evaluated during the cluster randomized trial by Baqui et al. Control group is families unable to comply with referral and were not offered treatment with injectable antibiotics at home.

This review of effectiveness of the interventions is shaped in large part by the needs of the LiST model. In that model, increasing coverage of an intervention results in a reduction in deaths due to one or more specific causes or in reduction of a risk factor. Therefore the reviews and the GRADE process used were designed to develop estimates of the effect of an intervention in reducing death due to specific causes. For more details of the review methods, the adapted GRADE approach or the LiST model see related publications [6,7].

To our knowledge, this is the first review providing effectiveness estimates for case management options to reduce neonatal deaths due to neonatal sepsis/meningitis and pneumonia, in both community and facility settings. Theodoratou et al have previously estimated effectiveness of pneumonia case management in children under 5 years but they did not disaggregate neonatal mortality data from later child mortality [77]. The estimated effect of community case management on pneumonia mortality in children under 5 years of age in the analysis by Theodoratou et al is 70\% (77). Oral antibiotics in community settings for neonatal pneumonia in our analysis were associated with a $42 \%$ reduction in pneumonia-specific mortality and a $25 \%$ reduction in all-cause neonatal mortality based on a meta-analysis of available trials. There is no evidence to estimate the effect of oral antibiotics on sepsis-specific mortality, but our Delphi process suggested a 28\% reduction. Delphiderived estimates for the effects of management using injectable antibiotics delivered in home or primary care settings came out at $65 \%$ for sepsis-specific mortality and $75 \%$ for pneumonia-specific mortality. These 


\section{Outcome: all-cause mortality}

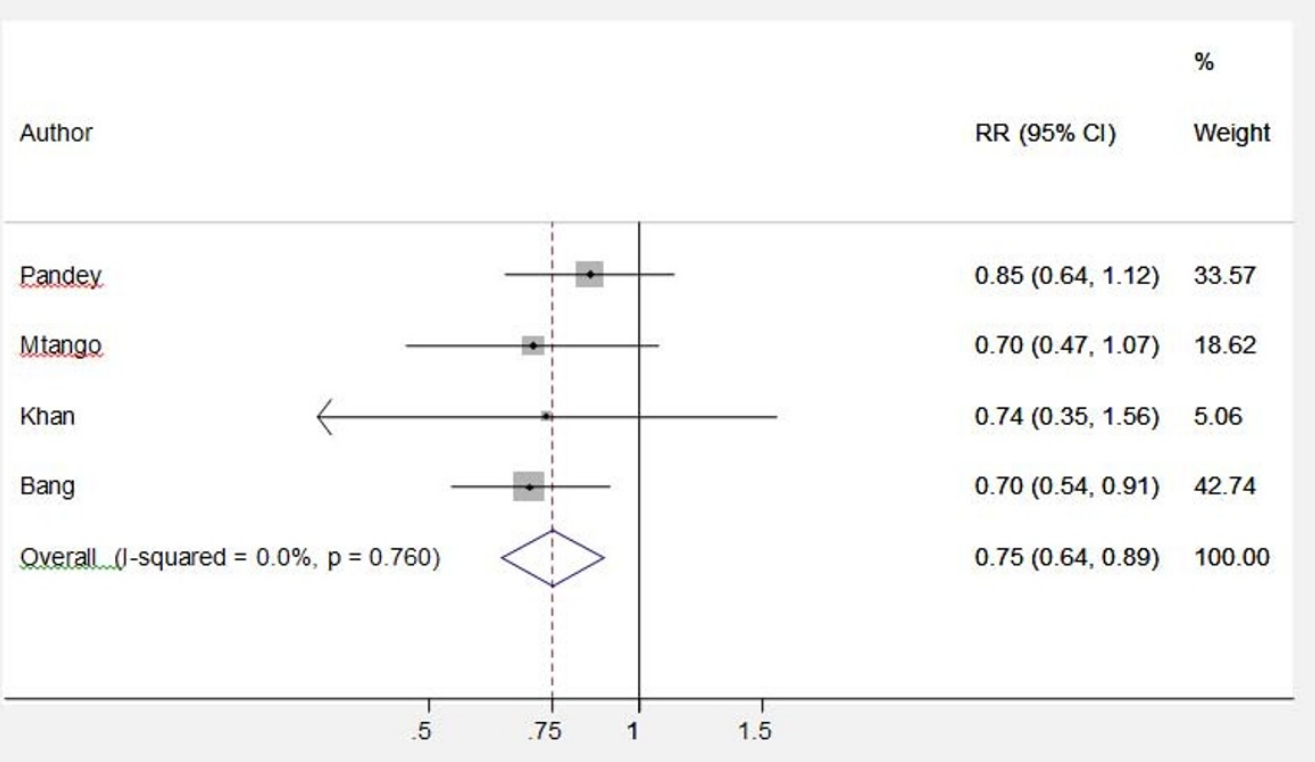

Figure 4 Meta-analysis of observational studies comparing oral antibiotics versus none in the community setting for babies: All cause mortality. Legend: Heterogeneity chi-squared $=1.17($ d.f. $=3) p=0.760$ l-squared (variation in RR attributable to heterogeneity) $=0.0 \%$ Test of RR=1 : $z=$ $3.32 \mathrm{p}=0.001$

\section{Outcome: pneumonia mortality}

Author

Pandey

Mtango

Bang

Overall (I-squared $=7.5 \%, p=0.339)$

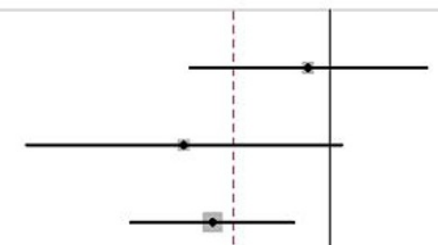

$\mathrm{RR}(95 \% \mathrm{Cl})$

$\%$

Weight

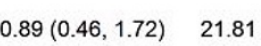

$0.44(0.18,1.07) \quad 19.28$

$0.52(0.33,0.82) \quad 58.91$

$0.58(0.41,0.82) \quad 100.00$

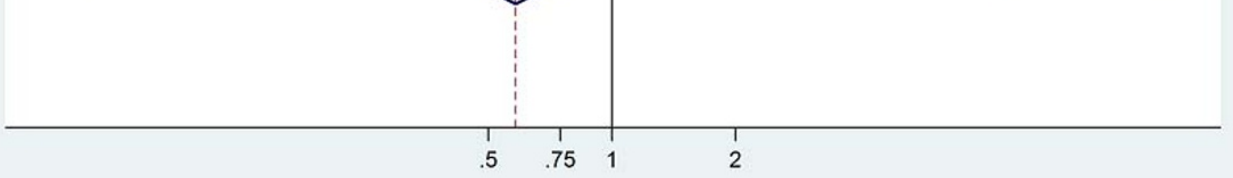

Figure 5 Meta-analysis of observational studies comparing oral antibiotics versus none in the community setting for babies: Pneumonia mortality. Legend: Heterogeneity chi-squared $=2.16($ d.f. $=2) p=0.339$ I-squared (variation in RR attributable to heterogeneity) $=7.5 \%$ Test of $R R=1: z=3.06 p=0.002$. 


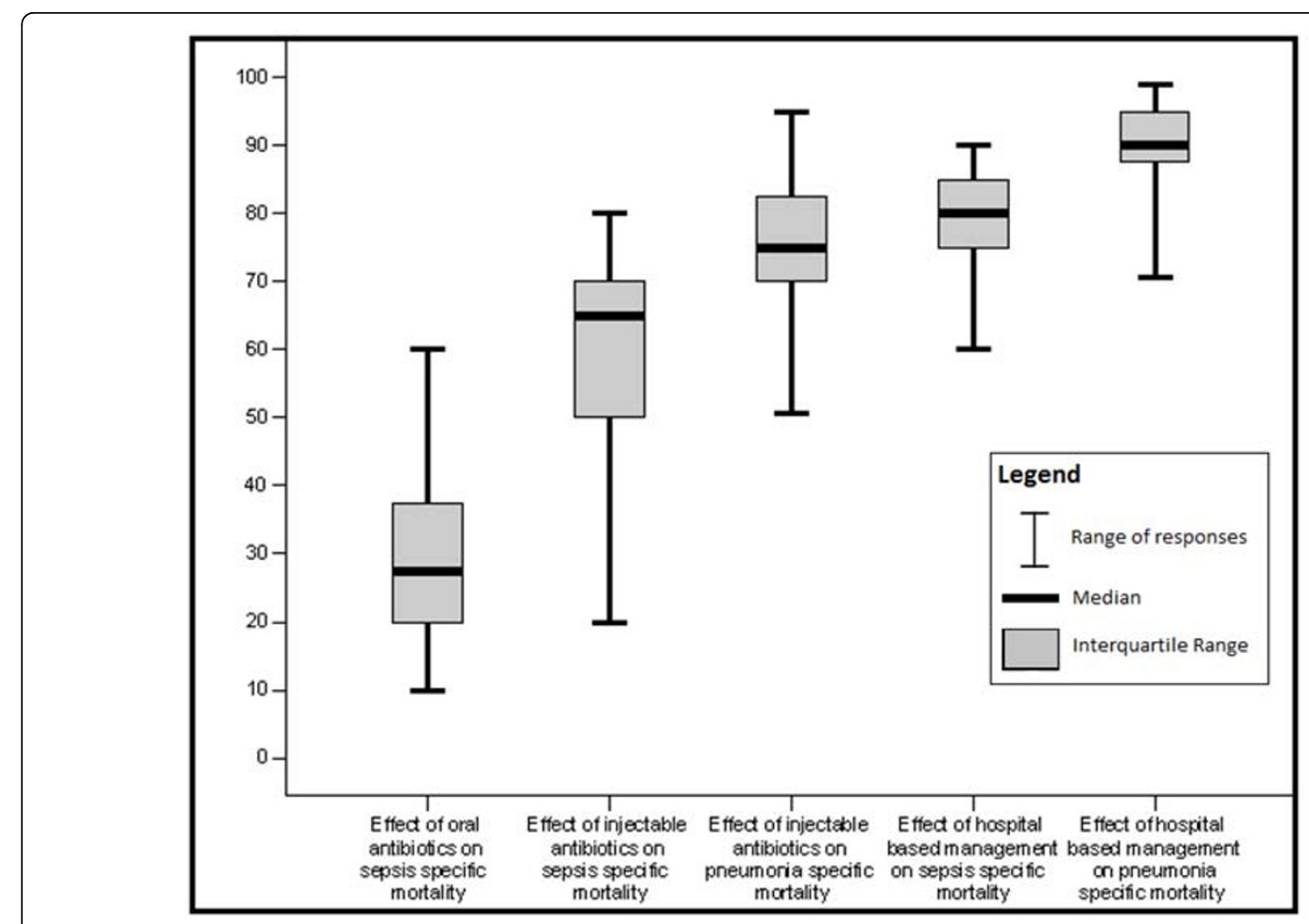

Figure 6 Box plot of Delphi expert opinion estimates of reduction in neonatal cause specific mortality due to pneumonia and sepsis/meningitis.

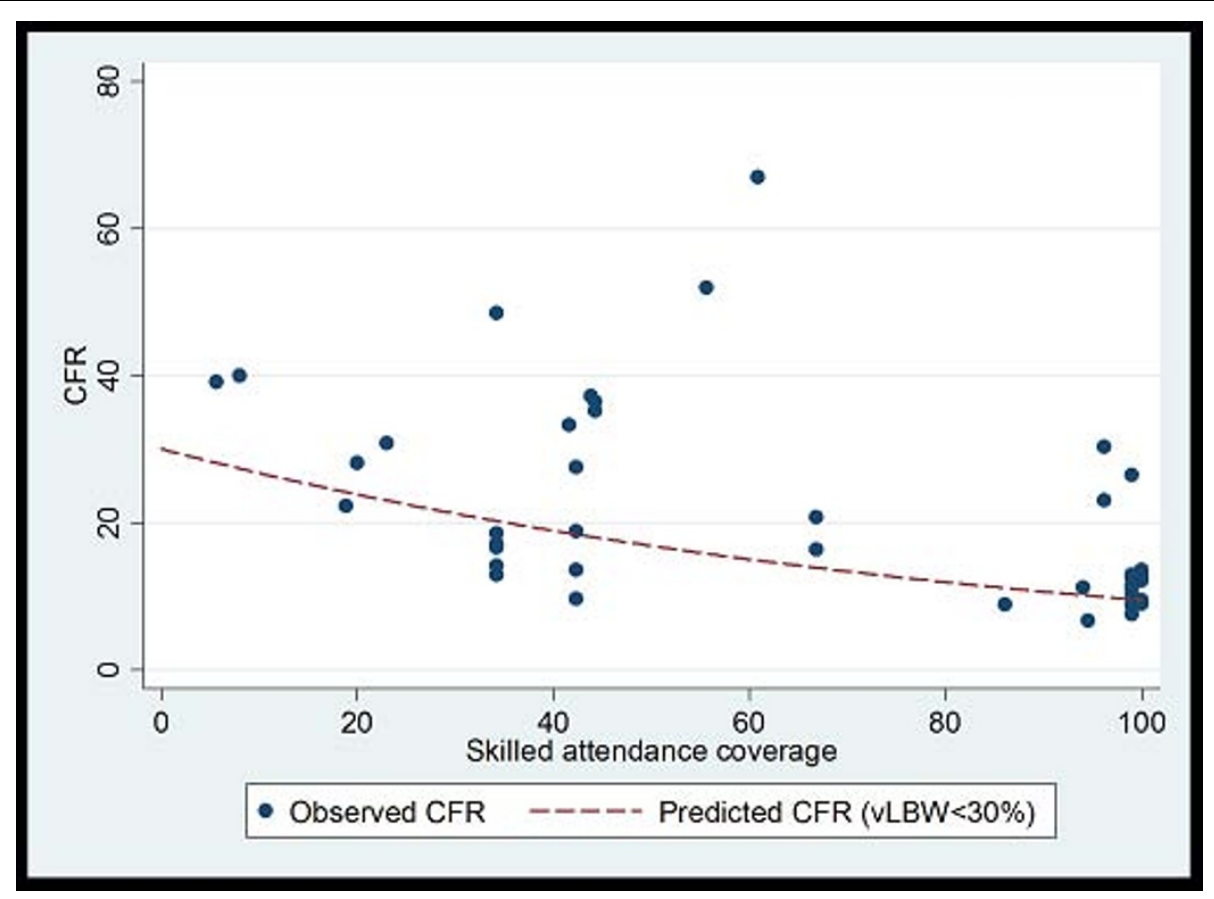

Figure 7 Plot of neonatal sepsis CFR versus percent skilled delivery as a marker of access to facility care. Model fitted: outcome $=\log (C F R)$ Covariates $=$ Skilled attendant coverage and $\%$ babies vLBW Fitted line is predicted CFR for settings with \% VLBW $<30 \%$. Predicted CFR at $0 \%$ skilled attendance is $30 \%$. Predicted CFR at $100 \%$ skilled attendance is $9.5 \% . \%$ reduction $=68.5 \%$ Coefficient skilled attendance is 0.12 on the log scale ( $95 \% \mathrm{Cl}-0.02$ to -0.007 ); i.e. for each $1 \%$ increase in skilled attendance rate CFR is reduced by $1.1 \%$ ( $95 \%$ Cl: $0.7 \%$ to $1.6 \%$ ). 
Table 7 Effect of case management on neonatal sepsis and pneumonia cause specific mortality, and GRADE of the estimate

\begin{tabular}{ll}
\hline Effect on neonatal deaths due to pneumonia & \\
\hline Cause specific effect and 95\% CI/ interquartile range: & \\
Oral therapy & $42 \%(18-59 \%, 95 \% \mathrm{Cl})$ \\
Injection therapy & $75 \%(70-81 \%$ interquartile range on Delphi) \\
Hospital-based case management & $90 \%(89-95 \%$ interquartile range on Delphi) \\
\hline
\end{tabular}

\section{Quality of input evidence:}

For oral therapy, moderate (3 low quality non-randomized concurrent control studies)

For the effects of injection therapy and full case management, the level of evidence is very low (based on Delphi).

Proximity of the data to cause specific mortality effect:

Moderate for oral therapy as several low quality but consistent studies; however, lack of consistency in cause-of-death definitions

Very low quality for injection therapy and full case management as these results are based on Delphi

Limitations of the evidence:

Interpretation of the data is limited by concurrent interventions particularly for studies with injection case management

\section{Possible adverse effects:}

Data not reviewed

\begin{tabular}{ll}
\hline Effect on neonatal deaths due to sepsis and meningitis \\
\hline Cause specific effect and interquartile range: & \\
Oral therapy & $28 \%(20-36.25 \%$ interquartile range on Delphi) \\
Injection therapy & $65 \%(50-70 \%$ interquartile range on Delphi) \\
Hospital-based management & $80 \%(75-85 \%$ interquartile range on Delphi)
\end{tabular}

Quality of input evidence:

Very low (based on Delphi)

Proximity of the data to cause specific mortality effect:

Direct effect estimated by Delphi

Limitations of the evidence:

Lack of direct evidence on sepsis-specific mortality. Studies have evaluated injectable antibiotics as part of multiple co-intervention peri-natal care packages.

Possible adverse effects:

Data not reviewed

estimates are biologically plausible and consistent with published studies $[9,12]$ which reported reductions in all-cause neonatal mortality (sepsis plus other causes) of $34 \%$ and $44 \%$ respectively with community-based packages including injectable antibiotics. CFRs reported from observational studies of hospital case management varied widely, from 6.7 to $67 \%$. Our Delphi estimates suggested an $80 \%$ mortality reduction in sepsis deaths and a $90 \%$ reduction in pneumonia deaths with hospital case management.

There were 4 effectiveness trials assessing the impact of oral antibiotics on pneumonia-specific mortality in the community. Only one of these studies was randomized and the programmatic coverage of the intervention had to be estimated as coverage data were not routinely assessed or reported. The selection and intensity of co-interventions was not uniform between the studies. An additional limitation was the lack of clearly defined cause-of-death definitions by the authors. However, the effect sizes were remarkably consistent with each other, and therefore the evidence level was upgraded to moderate.

GRADE guidelines rank the evidence relating to the effect of injectable antibiotics on sepsis-specific mortality as low quality. The 3 studies identified were not uniform with respect to study designs; one was an effectiveness RCT, one was a non-randomized concurrent trial and the third was an observational study describing the experience from primary care clinic without a control group. Both the RCT [12] and the non-randomized concurrent trial[9], involved concurrent co-interventions alongside the administration of injectable antibiotics. This made it impossible to assess the impact of injectable antibiotics alone on sepsis mortality. Neither study reported the change in the sepsis-specific mortality rate in the intervention arm compared to control arm, and reported the impact on all-cause neonatal mortality only. The absence of randomization in one of the trials is a further limitation [9]. The main limitation to the observational study in a 
primary care clinic [13] was the absence of a control arm in the study.

We identified no controlled trials assessing the effect of hospital-based case management of neonatal infections. Such studies would be difficult or impossible to implement in an ethical fashion. Thus studies were limited to reporting CFRs for neonatal sepsis and meningitis. The studies were from varied settings, from both industrialized and low income countries, and reported widely varying CFRs. Only 2 of these observational studies reported CFRs for pneumonia. One of these studies reported a very high CFR for pneumonia due, we believe, to the high proportion of LBW babies in the sample $(60 \%)$.

We found some moderate quality evidence for intervention packages including antibiotics in community settings but ironically data are most lacking at facility level, and district hospital level is a critical gap [78]. Unlike the LiST review on neonatal resuscitation which identified several before-after studies of facility based neonatal resuscitation reporting mortality data, we were unable to find similar before-after studies on the effect of hospital-based case management of sepsis/meningitis/ pneumonia. An understandable reason for this might be the ethical constraints precluding such studies. However, historical reviews from the pre-antibiotic era provide an insight into the CFR associated with untreated sepsis in facility settings. The best available evidence comes from the series of papers from Yale Medical Center reporting time trends for neonatal sepsis. These data show that in the 1920s and 1930s the CFR for blood culture confirmed sepsis stood at $90 \%[79,80]$. With the introduction of antibiotics, the CFR decreased to $45 \%$ by 1965 [81], and with the subsequent introduction of intensive care units and advanced life support it came down to $16 \%$ by 1988 [82], and $3 \%$ by 2003 [83]. Such data highlight the effectiveness of hospital-based management in preventing neonatal mortality from sepsis.

\section{Conclusion}

As evident from our results, even oral or injectable antibiotics alone are highly effective in reducing deaths from neonatal sepsis or pneumonia. These interventions hold great potential to reduce the 1 million neonatal deaths each year. If substantial reduction in neonatal mortality is desired, both, community and facility-based interventions are required, linked by functioning referral systems, giving the potential to prevent hundreds of thousands of avoidable newborn deaths every year.

\section{Funding}

This work was supported in part by a grant to the US Fund for UNICEF for Child Health Epidemiology Reference Group from the Bill \&Melinda Gates Foundation (grant 43386) to "Promote evidence-based decision making in designing maternal, neonatal and child health interventions in low- and middle-income countries", and by a grant to Save The Children USA from the Bill \& Melinda Gates Foundation (Grant 50124) for "Saving Newborn Lives".

\section{Additional material}

Additional file 1: Study identifiers and context

List of abbreviations used

CFR: Case Fatality Rate; CHERG: Child Health Epidemiology Reference Group; IMCI: Integrated Management of Childhood Illnesses; LiST: Lives Saved Tool; RCT: Randomized Controlled Trial.

\section{Acknowledgements}

We are grateful to Rajiv Bahl for insightful review of an earlier draft of this paper. We are also grateful to the members of the Delphi Expert Panel including Rajiv Bahl, Abhay Bang, Abdullah Baqui, Zulfiqar Bhutta, Robert Black, Simon Cousens, Gary Darmstadt, Mike English, Luis Huicho, David Isaacs, Joy Lawn, Patrick Mark, Kim Mulholland, David Osrin, Vinod Paul, Igor Rudan, Cindy Stephen, Barbara Stoll, Steven Wall and Anita Zaidi.

This article has been published as part of BMC Public Health Volume 11 Supplement 3, 2011: Technical inputs, enhancements and applications of the Lives Saved Tool (LiST). The full contents of the supplement are available online at http://www.biomedcentral.com/1471-2458/11?issue=S3.

\section{Author details}

${ }^{1}$ Department of Paediatrics and Child Health, the Aga Khan University, Karachi, Pakistan. 'London School of Tropical Medicine and Hygiene, London, UK. ${ }^{3}$ Johns Hopkins Bloomberg School of Public Health, International Health, Baltimore MD, USA. ${ }^{4}$ Saving Newborn Lives/Save the Children, Cape Town, South Africa.

\section{Authors' contributions}

$A Z$ and $J$ planned the review, SS and AZ undertook the searches and abstraction with input from $J$ and $H G$. SC undertook the meta-analyses. RB provided unpublished data from a previous investigator working group. $J$, $A Z$ and $A C C L$ planned the Delphi. All authors contributed to the manuscript.

\section{Competing interests}

The authors declare that they have no competing interests.

Published: 13 April 2011

\section{References}

1. Black RE, Cousens S, Johnson HL, Lawn JE, Rudan I, Bassani DG, Jha P, Campbell H, Walker CF, Cibulskis R, et al: Global, regional, and national causes of child mortality in 2008: a systematic analysis. Lancet 2010, 375(9730):1969-1987.

2. Darmstadt GL, Bhutta ZA, Cousens S, Adam T, Walker N, de Bernis L: Evidence-based, cost-effective interventions: how many newborn babies can we save? Lancet 2005, 365(9463):977-988.

3. Bhutta Z, Ali N, Hyder A, Wajid A: Perinatal and newborn care in Pakistan: seeing the unseen. Karachi: Oxford University Press; 2004.

4. Knippenberg R, Lawn JE, Darmstadt GL, Begkoyian G, Fogstad H, Walelign N, Paul VK: Systematic scaling up of neonatal care in countries. Lancet 2005, 365(9464):1087-1098.

5. Bhutta ZA, Darmstadt GL, Hasan BS, Haws RA: Community-based interventions for improving perinatal and neonatal health outcomes in developing countries: a review of the evidence. Pediatrics 2005, $115(2$ Suppl):519-617.

6. Boschi-Pinto C, Young M, Black RE: The Child Health Epidemiology Reference Group reviews of the effectiveness of interventions to reduce 
maternal, neonatal and child mortality. International journal of epidemiology 2010, 39(Suppl 1):i3-6

7. Walker N, Fischer-Walker C, Bryce J, Bahl R, Cousens S: Standards for CHERG reviews of intervention effects on child survival. International journal of epidemiology 2010, 39(Suppl 1):i21-31.

8. Atkins D, Best D, Briss PA, Eccles M, Falck-Ytter Y, Flottorp S, Guyatt GH, Harbour RT, Haugh MC, Henry D, et al: Grading quality of evidence and strength of recommendations. BMJ 2004, 328(7454):1490.

9. Bang AT, Bang RA, Baitule SB, Reddy MH, Deshmukh MD: Effect of homebased neonatal care and management of sepsis on neonatal mortality: field trial in rural India. Lancet 1999, 354(9194):1955-1961.

10. Bang AT, Bang RA, Tale O, Sontakke P, Solanki J, Wargantiwar R, Kelzarkar P: Reduction in pneumonia mortality and total childhood mortality by means of community-based intervention trial in Gadchiroli, India. Lancet 1990, 336(8709):201-206

11. Baqui AH, Arifeen SE, Williams EK, Ahmed S, Mannan I, Rahman SM, Begum N, Seraji HR, Winch PJ, Santosham M, et al: Effectiveness of homebased management of newborn infections by community health workers in rural Bangladesh. The Pediatric infectious disease journal 2009, 28(4):304-310.

12. Baqui AH, El-Arifeen $S$, Darmstadt GL, Ahmed S, Williams EK, Seraji HR, Mannan I, Rahman SM, Shah R, Saha SK, et al: Effect of community-based newborn-care intervention package implemented through two servicedelivery strategies in Sylhet district, Bangladesh: a cluster-randomised controlled trial. Lancet 2008, 371(9628):1936-1944.

13. Bhandari N, Bahl R, Bhatnagar V, Bhan MK: Treating sick young infants in urban slum setting. Lancet 1996, 347(9017):1774-1775.

14. Khan AJ, Khan JA, Akbar M, Addiss DG: Acute respiratory infections in children: a case management intervention in Abbottabad District, Pakistan. Bulletin of the World Health Organization 1990, 68(5):577-585

15. Mtango FD, Neuvians D: Acute respiratory infections in children under five years. Control project in Bagamoyo District, Tanzania. Transactions of the Royal Society of Tropical Medicine and Hygiene 1986, 80(6):851-858.

16. Pandey MR, Daulaire NM, Starbuck ES, Houston RM, McPherson K: Reduction in total under-five mortality in western Nepal through community-based antimicrobial treatment of pneumonia. Lancet 1991, 338(8773):993-997.

17. Sazawal S, Black RE: Effect of pneumonia case management on mortality in neonates, infants, and preschool children: a meta-analysis of community-based trials. The Lancet infectious diseases 2003, 3(9):547-556.

18. Adejuyigbe EA, Adeodu OO, ko-Nai KA, Taiwo O, Owa JA: Septicaemia in high risk neonates at a teaching hospital in Ile-lfe, Nigeria. East Afr Med $J$ 2001, 78(10):540-543.

19. Ahmed AS, Chowdhury MA, Hoque M, Darmstadt GL: Clinical and bacteriological profile of neonatal septicemia in a tertiary level pediatric hospital in Bangladesh. Indian Pediatr 2002, 39(11):1034-1039.

20. Ali Z: Neonatal bacterial septicaemia at the Mount Hope Women's Hospital, Trinidad. Ann Trop Paediatr 2004, 24(1):41-44.

21. Anyebuno $M$, Newman $M$ : Common causes of neonatal bacteraemia in Accra, Ghana. East Afr Med J 1995, 72(12):805-808.

22. Basu S, Rathore P, Bhatia BD: Predictors of mortality in very low birth weight neonates in India. Singapore Med J 2008, 49(7):556-560.

23. Bell $Y$, Barton M, Thame M, Nicholson A, Trotman H: Neonatal sepsis in Jamaican neonates. Ann Trop Paediatr 2005, 25(4):293-296.

24. Berger A, Salzer HR, Weninger M, Sageder B, Aspock C: Septicaemia in an Austrian neonatal intensive care unit: a 7-year analysis. Acta Paediatr 1998, 87(10):1066-1069.

25. Bhutta ZA, Yusuf K: Neonatal sepsis in Karachi: factors determining outcome and mortality. J Trop Pediatr 1997, 43(2):65-70.

26. Boo NY, Chor CY: Six year trend of neonatal septicaemia in a large Malaysian maternity hospital. J Paediatr Child Health 1994, 30(1):23-27.

27. Chang Chien HY, Chiu NC, Li WC, Huang FY: Characteristics of neonatal bacterial meningitis in a teaching hospital in Taiwan from 1984-1997. J Microbiol Immunol Infect 2000, 33(2):100-104.

28. Chang $C$, Chang WN, Huang LT, Huang SC, Chang YC, Hung PL, Tasi CY, Lu CH, Cheng BC, Lee PY, et al: Neonatal bacterial meningitis in southern Taiwan. Pediatr Neurol 2003, 29(4):288-294.

29. Cordero L, Rau R, Taylor D, Ayers LW: Enteric gram-negative bacilli bloodstream infections: 17 years' experience in a neonatal intensive care unit. Am J Infect Control 2004, 32(4):189-195.
30. Cordero L, Sananes M, Ayers LW: Bloodstream infections in a neonatal intensive-care unit: 12 years' experience with an antibiotic control program. Infect Control Hosp Epidemiol 1999, 20(4):242-246.

31. Daoud AS, al-Sheyyab M, bu-Ekteish F, Obeidat A, Ali AA, el-Shanti H: Neonatal meningitis in northern Jordan. J Trop Pediatr 1996, 42(5):267-270

32. Das PK, Basu K, Chakraborty P, Bhowmik PK: Clinical and bacteriological profile of neonatal infections in metropolitan city based medical college nursery. J Indian Med Assoc 1999, 97(1):3-5.

33. Das PK, Basu K, Chakraborty S, Basak M, Bhowmik PK: Early neonatal morbidity and mortality in a city based medical college nursery. Indian J Public Health 1998, 42(1):9-14.

34. Dawson KG, Emerson JC, Burns JL: Fifteen years of experience with bacterial meningitis. Pediatr Infect Dis J 1999, 18(9):816-822.

35. Galanakis E, Krallis N, Levidiotou S, Hotoura E, Andronikou S: Neonatal bacteraemia: a population-based study. Scand JI nfect Dis 2002, 34(8):598-601

36. Gebremariam A: Neonatal meningitis in Addis Ababa: a 10-year review. Ann Trop Paediatr 1998, 18(4):279-283

37. Ghiorghis B: Neonatal sepsis in Addis Ababa, Ethiopia: a review of 151 bacteremic neonates. Ethiop Med J 1997, 35(3):169-176.

38. Hervas JA, Alomar A, Salva F, Reina J, Benedi VJ: Neonatal sepsis and meningitis in Mallorca, Spain, 1977-1991. Clin Infect Dis 1993, 16(5):719-724

39. Ishikawa T, Asano Y, Morishima T, Nagashima M, Sobue G, Watanabe K, Yamaguchi H: Epidemiology of bacterial meningitis in children: Aichi Prefecture, Japan, 1984-1993. Pediatr Neurol 1996, 14(3):244-250.

40. Jeena PM, Adhikari M, Carlin JB, Qazi S, Weber MW, Hamer DH: Clinical profile and predictors of severe illness in young South African infants (<60 days). S Afr Med J 2008, 98(11):883-888.

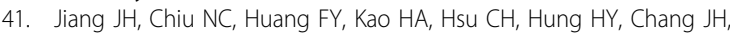
Peng CC: Neonatal sepsis in the neonatal intensive care unit: characteristics of early versus late onset. J Microbiol Immunol Infect 2004 37(5):301-306.

42. Kallman J, Kihlstrom E, Sjoberg L, Schollin J: Increase of staphylococci in neonatal septicaemia: a fourteen-year study. Acta Paediatr 1997, 86(5):533-538

43. Karthikeyan G, Premkumar K: Neonatal sepsis: Staphylococcus aureus as the predominant pathogen. Indian J Pediatr 2001, 68(8):715-717.

44. Karunasekera KA, Pathirana D: A preliminary study on neonatal septicaemia in a tertiary referral hospital paediatric unit. Ceylon Med $J$ 1999, 44(2):81-86.

45. Kuruvilla KA, Pillai $S$, Jesudason $M$, Jana AK: Bacterial profile of sepsis in a neonatal unit in south India. Indian Pediatr 1998, 35(9):851-858

46. Laving AM, Musoke RN, Wasunna AO, Revathi G: Neonatal bacterial meningitis at the newborn unit of Kenyatta National Hospital. East Afr Med J 2003, 80(9):456-462.

47. Lee NC, Chen SJ, Tang RB, Hwang BT: Neonatal bacteremia in a neonatal intensive care unit: analysis of causative organisms and antimicrobial susceptibility. J Chin Med Assoc 2004, 67(1):15-20.

48. Lim NL, Wong YH, Boo NY, Kasim MS, Chor CY: Bacteraemic infections in a neonatal intensive care unit-a nine-month survey. Med J Malaysia 1995, 50(1):59-63

49. Lopez Sastre JB, Fernandez CB, Coto Cotallo GD, Ramos AA: Trends in the epidemiology of neonatal sepsis of vertical transmission in the era of group B streptococcal prevention. Acta Paediatr 2005, 94(4):451-457.

50. Mathur NB, Singh A, Sharma VK, Satyanarayana L: Evaluation of risk factors for fatal neonatal sepsis. Indian Pediatr 1996, 33(10):817-822

51. Milledge J, Calis JC, Graham SM, Phiri A, Wilson LK, Soko D, Mbvwinji M, Walsh AL, Rogerson SR, Molyneux ME, et al: Aetiology of neonatal sepsis in Blantyre, Malawi: 1996-2001. Ann Trop Paediatr 2005, 25(2):101-110.

52. Moore KL, Kainer MA, Badrawi N, Afifi S, Wasfy M, Bashir M, Jarvis WR, Graham TW, el-Kholy A, Gipson R, et al: Neonatal sepsis in Egypt associated with bacterial contamination of glucose-containing intravenous fluids. Pediatr Infect Dis J 2005, 24(7):590-594.

53. Moreno MT, Vargas S, Poveda R, Saez-Llorens X: Neonatal sepsis and meningitis in a developing Latin American country. Pediatr Infect Dis $J$ 1994, 13(6):516-520.

54. Nnpd: Neonatal morbidity and mortality: report of the National Neonatal-Perinatal Database. Indian Pediatr 1997, 34(11):1039-1042. 
55. Palmer A, Weber M, Bojang K, McKay T, Adegbola R: Acute bacterial meningitis in The Gambia: a four-year review of paediatric hospital admissions. J Trop Pediatr 1999, 45(1):51-53.

56. Park $\mathrm{CH}$, Seo JH, Lim JY, Woo HO, Youn HS: Changing trend of neonatal infection: experience at a newly established regional medical center in Korea. Pediatr Int 2007, 49(1):24-30.

57. Patel DM, Rhodes PG, LeBlanc MH, Graves GR, Glick C, Morrison J: Role of postnatal penicillin prophylaxis in prevention of neonatal group $B$ streptococcus infection. Acta Paediatr 1999, 88(8):874-879.

58. Persson E, Trollfors B, Brandberg LL, Tessin I: Septicaemia and meningitis in neonates and during early infancy in the Goteborg area of Sweden. Acta Paediatr 2002, 91(10):1087-1092.

59. Robillard PY, Perez JM, Hulsey TC, Perianin J, Gallais A, Janky E: Evaluation of neonatal sepsis screening in a tropical area. Part l: Major risk factors for bacterial carriage at birth in Guadeloupe. West Indian Med J 2000, 49(4):312-315

60. Simiyu DE: Morbidity and mortality of neonates admitted in general paediatric wards at Kenyatta National Hospital. East Afr Med J 2003, 80(12):611-616.

61. Simiyu DE: Neonatal septicaemia in low birth weight infants at Kenyatta National Hospital, Nairobi. East Afr Med J 2005, 82(3):148-152.

62. Smith PB, Cotten CM, Garges HP, Tiffany KF, Lenfestey RW, Moody MA, Li JS, Benjamin DK Jr.: A comparison of neonatal Gram-negative rod and Gram-positive cocci meningitis. J Perinatol 2006, 26(2):111-114.

63. Sundaram V, Kumar P, Dutta S, Mukhopadhyay K, Ray P, Gautam V, Narang A: Blood culture confirmed bacterial sepsis in neonates in a North Indian tertiary care center: changes over the last decade. J Infect Dis 2009, 62(1):46-50.

64. Tiskumara R, Fakharee $\mathrm{SH}$, Liu CQ, Nuntnarumit $\mathrm{P}$, Lui KM, Hammoud M, Lee JK, Chow CB, Shenoi A, Halliday R, et al: Neonatal infections in Asia. Arch Dis Child Fetal Neonatal Ed 2009, 94(2):F144-F148.

65. Trotman H, Bell Y, Thame M, Nicholson AM, Barton M: Predictors of poor outcome in neonates with bacterial sepsis admitted to the University Hospital of the West Indies. West Indian Med J 2006, 55(2):80-84.

66. Udo JJ, Anah MU, Ochigbo SO, Etuk IS, Ekanem AD: Neonatal morbidity and mortality in Calabar, Nigeria: a hospital-based study. Niger J Clin Pract 2008, 11(3):285-289.

67. Waheed M, Laeeq A, Maqbool S: The etiology of neonatal sepsis and patterns of antibiotic resistance. J Coll Physicians Surg Pak 2003, 13(8):449-452.

68. Watson RS, Carcillo JA, Linde-Zwirble WT, Clermont G, Lidicker J, Angus DC: The epidemiology of severe sepsis in children in the United States. Am J Respir Crit Care Med 2003, 167(5):695-701.

69. Wolf H, Schaap AH, Smit BJ, Spanjaard L, Adriaanse AH: Liberal diagnosis and treatment of intrauterine infection reduces early-onset neonatal group B streptococcal infection but not sepsis by other pathogens. Infect Dis Obstet Gynecol 2000, 8(3-4):143-150.

70. Wolfler A, Silvani P, Musicco M, Antonelli M, Salvo I: Incidence of and mortality due to sepsis, severe sepsis and septic shock in Italian Pediatric Intensive Care Units: a prospective national survey. Intensive Care Med 2008, 34(9):1690-1697.

71. Kaushik SL, Parmar VR, Grover N, Grover PS, Kaushik R: Neonatal sepsis in hospital born babies. J Commun Dis 1998, 30(3):147-152.

72. Parkash J, Das N: Pattern of admissions to neonatal unit. J Coll Physicians Surg Pak 2005, 15(6):341-344.

73. Ganatra HA, Stoll BJ, Zaidi AK: International perspective on early-onset neonatal sepsis. Clin Perinatol 2010, 37(2):501-523.

74. Bhutta ZA, Zaidi AK, Thaver D, Humayun Q, Ali S, Darmstadt GL: Management of newborn infections in primary care settings: a review of the evidence and implications for policy? The Pediatric infectious disease journal 2009, 28(1 Suppl):S22-30.

75. Darmstadt GL, Batra M, Zaidi AK: Parenteral antibiotics for the treatment of serious neonatal bacterial infections in developing country settings. The Pediatric infectious disease journal 2009, 28(1 Suppl):S37-42.

76. Darmstadt GL, Batra M, Zaidi AK: Oral antibiotics in the management of serious neonatal bacterial infections in developing country communities. The Pediatric infectious disease journal 2009, 28(1 Suppl):S31-36.

77. Theodoratou E, Al-Jilaihawi S, Woodward F, Ferguson J, Jhass A, Balliet M, Kolcic I, Sadruddin S, Duke T, Rudan I, et al: The effect of case management on childhood pneumonia mortality in developing countries. International journal of epidemiology 39(Suppl 1):1155-171.
78. Bahl R, Martines J, Ali N, Bhan MK, Carlo W, Chan KY, Darmstadt GL, Hamer DH, Lawn JE, McMillan DD, et al: Research priorities to reduce global mortality from newborn infections by 2015 . The Pediatric infectious disease journal 2009, 28(1 Suppl):S43-48.

79. Dunham EC: Septicemia in the new-born. Archives of Pediatrics \& Adolescent Medicine 1933, 45(2):229-253.

80. Nyhan WL, Fousek MD: Septicemia of the newborn. Pediatrics 1958, 22(2):268-278.

81. Gluck L, Wood HF, Fousek MD: Septicemia of the newborn. Pediatr Clin North Am 1966, 13(4):1131-1148.

82. Gladstone IM, Ehrenkranz RA, Edberg SC, Baltimore RS: A ten-year review of neonatal sepsis and comparison with the previous fifty-year experience. The Pediatric infectious disease journal 1990, 9(11):819-825.

83. Bizzarro MJ, Raskind C, Baltimore RS, Gallagher PG: Seventy-five years of neonatal sepsis at Yale: 1928-2003. Pediatrics 2005, 116(3):595-602.

84. Young Infants Clinical Signs Study Group. Clinical signs that predict severe illness in children under age 2 months: a multicentre study. Lancet 2008, 371(9607):135-142.

doi:10.1186/1471-2458-11-S3-S13

Cite this article as: Zaidi et al:: Effect of case management on neonatal mortality due to sepsis and pneumonia. BMC Public Health 2011 11(Suppl 3):S13.

\section{Submit your next manuscript to BioMed Central and take full advantage of:}

- Convenient online submission

- Thorough peer review

- No space constraints or color figure charges

- Immediate publication on acceptance

- Inclusion in PubMed, CAS, Scopus and Google Scholar

- Research which is freely available for redistribution

Submit your manuscript at www.biomedcentral.com/submit
C Biomed Central 